\title{
Atmospheric Mercury Concentrations Near Salmon Falls Creek Reservoir - Phase 1
}

\author{
Michael L. Abbott
}

October 2005

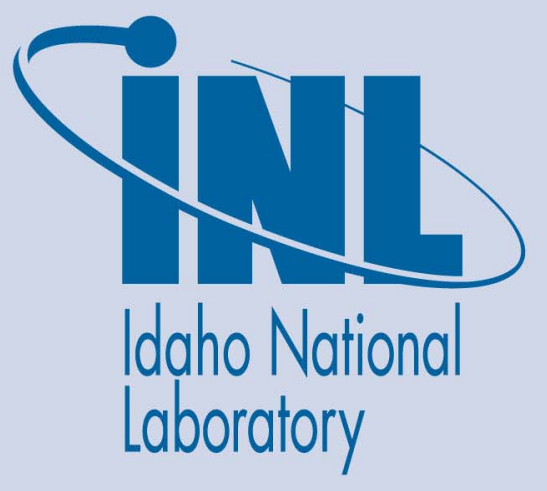

The INL is a U.S. Department of Energy National Laboratory operated by Battelle Energy Alliance 
INL/EXT-05-00767

\section{Atmospheric Mercury Concentrations Near Salmon Falls Creek Reservoir - Phase 1}

Michael L. Abbott

October 2005

Idaho National Laboratory

Idaho Falls, Idaho 83415

Prepared for the

Idaho Department of Environmental Quality

and the U.S. Department of Energy

Under DOE Idaho Operations Office

Contract DE-AC07-05ID14517 


\title{
Atmospheric Mercury Concentrations near Salmon Falls Creek Reservoir - Phase 1
}

\author{
INL/EXT-05-000767
}

October 2005

Approved by 


\section{ABSTRACT}

Elemental and reactive gaseous mercury (EGM/RGM) were measured in ambient air concentrations over a two-week period in July/August 2005 near Salmon Falls Creek Reservoir, a popular fishery located 50 $\mathrm{km}$ southwest of Twin Falls, Idaho. A fish consumption advisory for mercury was posted at the reservoir in 2002 by the Idaho Department of Health and Welfare. The air measurements were part of a multimedia (water, sediment, precipitation, air) study initiated by the Idaho Department of Environmental Quality and the U.S. Environmental Protection Agency (EPA) Region 10 to identify potential sources of mercury contamination to the reservoir. The sampling site is located about $150 \mathrm{~km}$ northeast of large gold mining operations in Nevada, which are known to emit large amounts of mercury to the atmosphere (est. 2,200 kg/y from EPA 2003 Toxic Release Inventory). The work was co-funded by the Idaho National Laboratory's Community Assistance Program and has a secondary objective to better understand mercury inputs to the environment near the INL, which lies approximately $230 \mathrm{~km}$ to the northeast.

Sampling results showed that both EGM and RGM concentrations were significantly elevated $(\sim 30-$ $70 \%, \mathrm{P}<0.05)$ compared to known regional background concentrations. Elevated short-term RGM concentrations (the primary form that deposits) were likely due to atmospheric oxidation of high EGM concentrations, which suggests that EGM loading from upwind sources could increase $\mathrm{Hg}$ deposition in the area. Back-trajectory analyses indicated that elevated EGM and RGM occurred when air parcels came out of north-central and northeastern Nevada. One EGM peak occurred when the air parcels came out of northwestern Utah. Background concentrations occurred when the air was from upwind locations in Idaho (both northwest and northeast). Based on 2003 EPA Toxic Release Inventory data, it is likely that most of the observed peaks were from Nevada gold mine sources. Emissions from known large natural mercury sources in that area cannot account for the observed EGM peaks due to their diffuse source geometry and the large $(170 \mathrm{~km})$ transport distance involved. The EGM peak originating from northwestern Utah air may be from three known mercury sources west of Salt Lake City (Kennecott, US Magnesium, Clean Harbors Aragonite) and/or the 1600 MW coal-fired Intermountain Power plant near Delta. However, the relative importance of these short-term peaks for long-term watershed mercury loading (critical factor affecting fish concentrations) is not known, and there is a need to better quantify the annual frequency and magnitude of these different inputs over a longer period of time. 


\section{ACKNOWLEDGMENTS}

I would like to thank the Idaho Department of Environmental Quality and EPA Region 10 for funding support. Rick Hardy, Mike Dubois, and Bruce Louks at IDEQ provided great technical support and guidance throughout the project. Bob Kotchenruther at EPA Region 10 provided generous help with back-trajectory modeling. Chuck Briggs, director of the INL Work for Others program, provided additional funding support which made completion of the work possible. Finally, I would like to thank my summer Science Action Team teacher, Holly Davis, and students, Sarah Gutterud and John Elias, who helped with logistics and fieldwork. 


\section{CONTENTS}

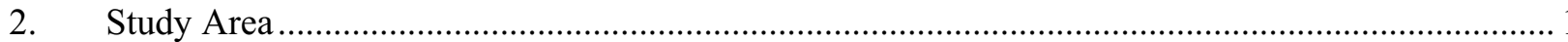

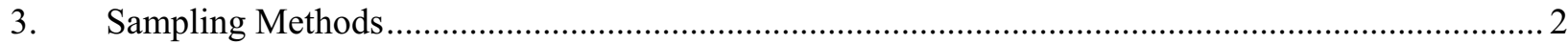

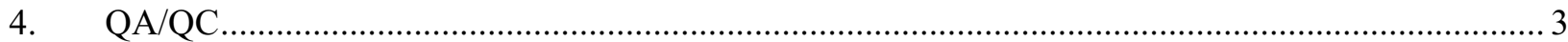

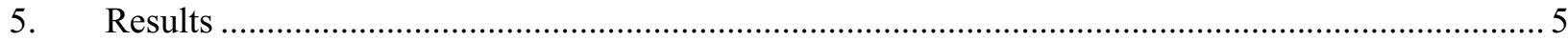

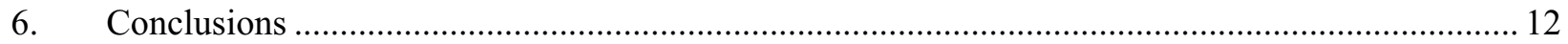

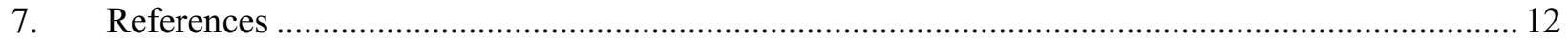

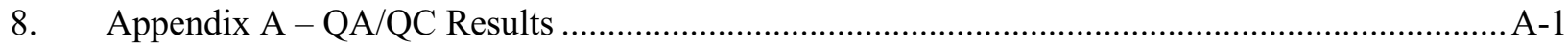

9. $\quad$ Appendix B - Processed Tekran Data ….................................................................................. B-1

10. Appendix C - INL Tekran Mercury Measurement System QA/QC Protocol ............................. C-1

\section{FIGURES}

Figure 1. Study area showing the Swan Ranch sampling location, SFCR and its watershed, and known large mercury emission sources in the region (windrose shown is for Elko, NV in September; MDN - Mercury Deposition Network monitor).

Figure 2. INL Mobile Hg Monitoring Lab with Tekran® instrumentation (1130 quartz denuder module shown on 4-m high tower).

Figure 3. Variability in daily permeation source calibrations was $\pm 1.3 \%$ for both A and B cartridges. ..... 4

Figure 4. 80-min EGM concentrations measured over the 2-week sampling period at Swan Ranch......... 5

Figure 5. Comparison of measured EGM concentrations with regional background measured on the Snake River Plain (SRP) in southeastern Idaho and at Mt. Bachelor (MBO) in central Oregon (error bars are \pm 1 standard deviation).

Figure 6. Comparison of EGM at Swan Ranch with EGM measured at SRP over the same 2-week period in 2004. The Swan average was significantly greater than the SRP average $(\mathrm{p}<0.05) \ldots \ldots \ldots \ldots \ldots \ldots .6$

Figure 7. EGM and RGM concentrations measured at Swan Ranch................................................... 7

Figure 8. RGM concentrations measured at Swan Ranch compared to RGM on the SRP in 2004........... 7

Figure 9. Back-trajectory plots of sampling events shown in Figure 4 (3 trajectories - red, blue, greenshown for 24-hour flow paths ending 1 hour prior to, during, and 1 hour after the event) 
Figure 10. Concentrations from southwest and southeast wind trajectories were significantly greater than concentrations from the northwest and northeast.

\section{TABLES}

Table A-1. Daily Tekran permeation source output................................................................................ A-1

Table A-2. Tekran sample system zero air and standard addition checks on 7/22, 7/29, and 8/5/05......A-2

Table B-1. Processed Tekran data for July 22 - August 5, 2005 sampling at Swan Ranch.................... B-1 


\section{Atmospheric Mercury Concentrations near Salmon Falls Creek Reservoir - Phase 1}

\section{Introduction}

This report documents the results of mercury air sampling that was conducted for the Idaho Department of Environmental Quality (IDEQ) near Salmon Falls Creek Reservoir (SFCR), in southcentral Idaho from July 22 through August 5, 2005. The air measurements were part of a multi-media (water, sediment, precipitation, air) study initiated by the IDEQ to identify potential sources of mercury contamination to the reservoir. A fish consumption advisory for mercury was posted at the reservoir in 2002 by the Idaho Department of Health and Welfare based on sampled fish tissue concentrations which exceeded the $0.3 \mathrm{ppm}$ EPA fish tissue criterion. Atmospheric transport and deposition is known to be a primary transport pathway for mercury to watersheds and water bodies. Mercury air emissions from coalfired power plants, waste incinerators, precious metal ore roasting, and other sources can be transported long distances before ultimately depositing in watersheds. After deposition, a portion of the mercury enters streams and lakes where it can bioaccumulate to high levels in predatory game fish. Much of the mercury that is deposited within a state may be generated from emission sources outside that state (EPA 2005).

The air sampling was performed to determine whether there is an atmospheric component of mercury input that could be causing the high mercury concentrations in fish and to identify where the atmospheric mercury might be coming from. The sampling was also performed to quantify background atmospheric inputs (or baseline concentrations) of mercury in the region to better assess impacts from local mercury air emissions sources in Idaho. The work was co-funded by the Idaho National Laboratory's (INL) Community Assistance Program. The INL is located about $230 \mathrm{~km}$ northeast of SFCR in a generally downwind direction.

Both elemental gaseous mercury (EGM) and reactive gaseous mercury (RGM) were measured. EGM accounts for most ( $>95 \%$ ) of the mercury in the atmosphere, is relatively inert, and does not deposit readily. RGM includes several types of oxidized species (mostly $\mathrm{Hg}^{+2}$ ), is highly reactive (soluble), deposits at a high rate, and is generally the species of concern for watershed contamination. Although EGM does not deposit readily, it is of concern because a portion of it may be converted to RGM by atmospheric oxidation.

\section{Study Area}

SFCR is located in a remote area in south-central Idaho about $50 \mathrm{~km}$ southwest of Twin Falls (Figure 1). The sampling location was at Swan Ranch on House Creek located about $20 \mathrm{~km}$ west of SFCR at an elevation of $5690 \mathrm{ft}$. This site was selected because IDEQ had previously conducted air sampling at this location and electric power was available. The Swan Ranch site is located in the lower portion of the SFCR watershed (Figure 1), with most ( $60 \%)$ of the watershed lying in northeastern Nevada. Prevailing surface winds in the SFCR watershed generally blow from the west to southwest out of northern Nevada, but local scale patterns are highly influenced by solar energy and topographic features, the most important of which are the 10,000-ft high Jarbidge Mountains 50-km southwest of the sampling location.

There are numerous mercury air emission sources in the region, most of which are identified in Figure 1. The largest of these are gold mining operations in northeastern Nevada that have total annual $\mathrm{Hg}$ air emissions of 4,807 lbs/yr based on EPA's 2003 Toxic Release Inventory (TRI)

(http://www.epa.gov/tri/). The closest of these mines is Jerritt Canyon, located about $120 \mathrm{~km}$ southwest of the sampling location. The following five gold mines shown in Figure 1 accounted for most (4,776 lbs/yr) 
of the mine $\mathrm{Hg}$ emissions (listed by distance from the sampling location): (1) Jerritt Canyon - $790 \mathrm{lbs} / \mathrm{yr}$, (2) Twin Creeks - $588 \mathrm{lbs} / \mathrm{yr}$, (3) Barrick Goldstrike - 1,452 lbs/yr, (4) Carlin South - $565 \mathrm{lbs} / \mathrm{yr}$, and (5) Cortez - 1,381 lbs/yr. Other known mercury sources in the region include Ash Grove Cement in eastern Oregon - 572 lbs/yr; P4 Production in southeastern Idaho - 620 lbs/yr; Nucor Steel in northern Utah $110 \mathrm{lbs} / \mathrm{yr}$; three sources west of Salt Lake City--US Magnesium, Clean Harbors Aragonite, and Kennecott - $300 \mathrm{lbs} / \mathrm{yr}$ total; and the large (1600 MW) Intermountain Power Station in west-central Utah $-223 \mathrm{lbs} / \mathrm{yr}$ (all 2003 TRI estimates).

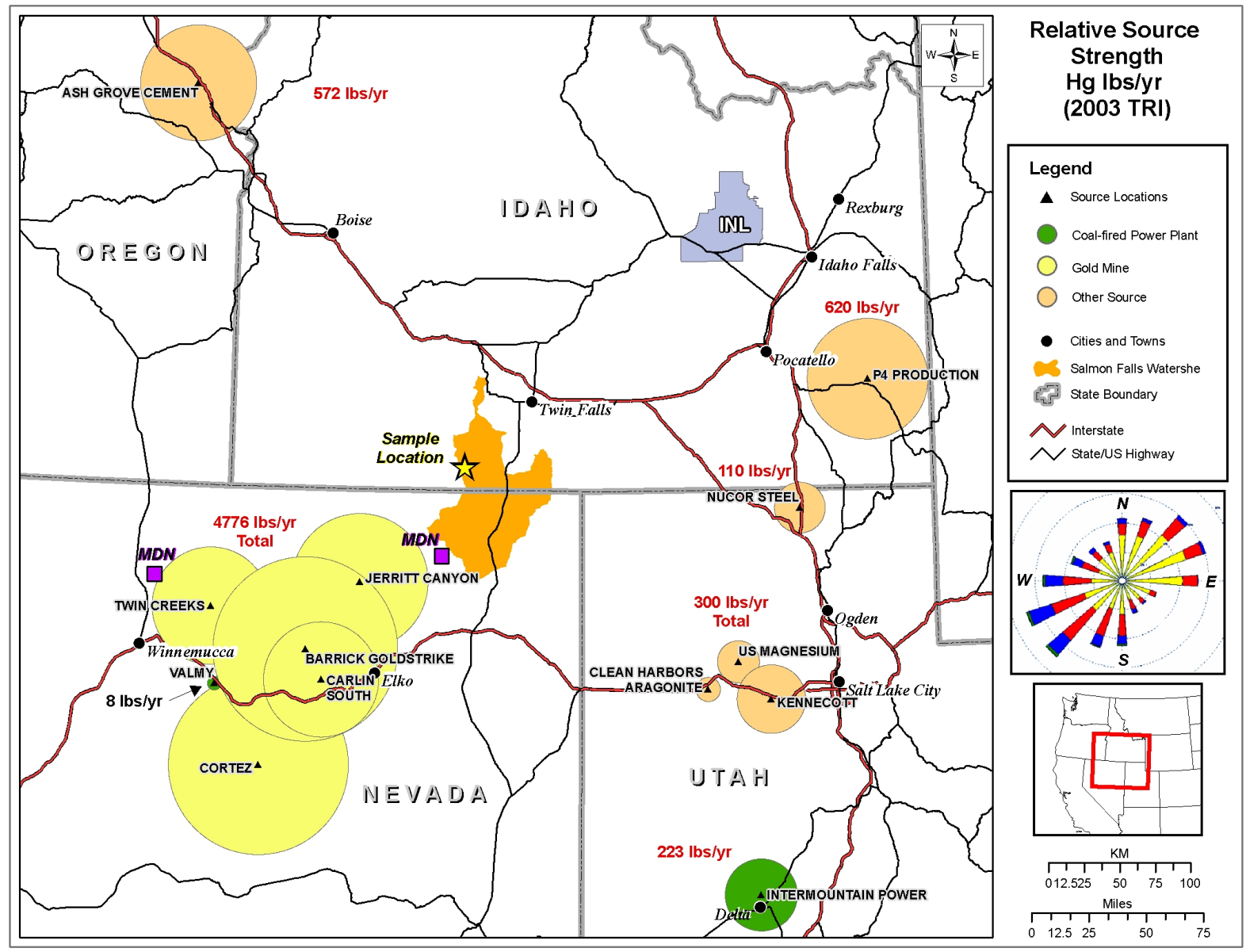

Figure 1. Study area showing the Swan Ranch sampling location, SFCR and its watershed, and known large mercury emission sources in the region (windrose shown is for Elko, NV in September; MDN Mercury Deposition Network monitor).

\section{Sampling Methods}

Continuous elemental gaseous mercury (EGM) and reactive gaseous mercury (RGM) measurements were made at the Swan Ranch site from July 22, 2005 through August 5, 2005 (14 days) using the INL's Mobile Hg Monitoring Lab (Figure 2). This is a 7 x 14-ft self-contained, temperature- 
controlled instrument trailer that houses a Tekran ${ }^{\circledR}{ }^{\mathrm{a}} 2537 \mathrm{~A}$ mercury vapor analyzer, a Tekran ${ }^{\circledR} 1130$ speciation unit, zero (mercury-free) air generator, mercury vapor calibration unit, and data logging laptop computer. The 2537A uses dual gold cartridge absorption of mercury followed by thermal desorption and cold vapor atomic fluorescence and provides continuous 5-minute average measurements of EGM. The 1130 speciation unit uses KCl-coated quartz denuder technology to efficiently ( $>94 \%$ ) capture RGM, which includes several species of ionic mercury $\left(\right.$ mostly $\mathrm{Hg}^{+2}$ ) that cannot make it through the heated sample line. The RGM is thermally desorbed from the denuder after $80 \mathrm{~min}$ and measured by the 2537A, providing an 80-min average RGM concentration every 2 hours. The 5-min EGM measurements are typically averaged over the 80-min RGM averaging time. The sample inlet for both the RGM and EGM measurement is $4 \mathrm{~m}$ above ground level (Figure 2).

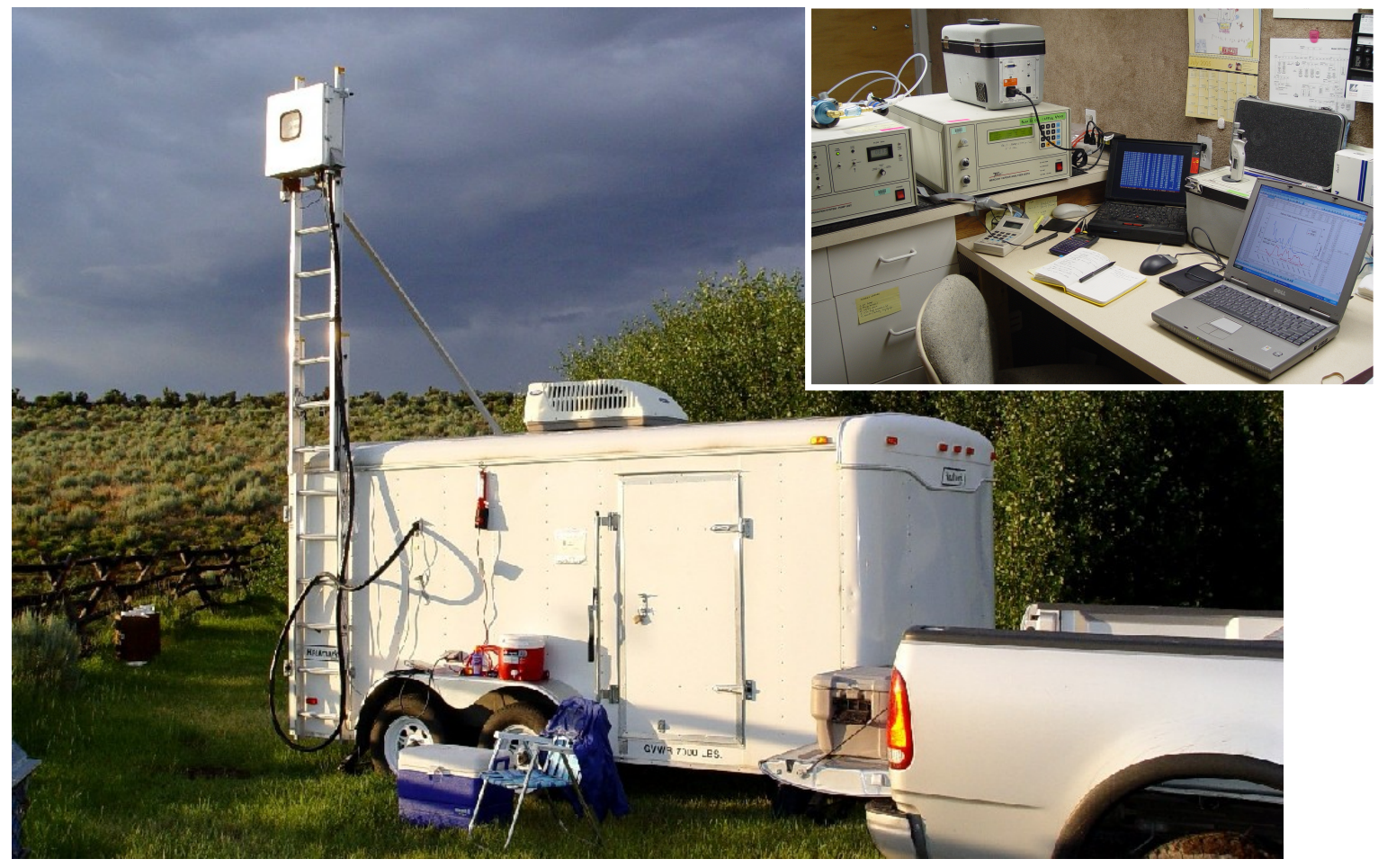

Figure 2. INL Mobile Hg Monitoring Lab with Tekran® instrumentation (1130 quartz denuder module shown on 4-m high tower).

\section{4. $\mathbf{Q A} / \mathrm{QC}$}

Because of the ultra low-levels (picograms per cubic meter of air) of mercury that are being measured, the ubiquitous nature of mercury (cross-contamination problems), and the sensitivity of the instruments, rigorous QA/QC procedures were followed during all sampling. These procedures are documented in the "INL Tekran Field Sampling Protocol" (Appendix C) and are summarized below:

1. The 2537A analyzer is calibrated on a 6-month basis using digital syringe injections of mercury vapor from the Tekran ${ }^{\circledR} 2505$ mercury vapor primary calibration unit. The last calibration prior to this deployment was completed in April 2005.

\footnotetext{
${ }^{a}$ References herein to any specific commercial product, process, or service by trade name, trademark, manufacturer, or otherwise, does not necessarily constitute or imply its endorsement, recommendation, or favoring by the U.S. Government, any agency thereof, or any company affiliated with the Idaho National Laboratory.
} 
2. Daily calibrations were performed using the $2537 \mathrm{~A}$ internal permeation source. The coefficient of variation for these daily calibrations for both $2537 \mathrm{~A}$ gold cartridges was $1.3 \%$. The Tekran output for these permeation source calibrations are contained in Appendix A.

3. Precision of the 2537 A was checked prior to sampling (June 28,2005 ) and found to be $\pm 6 \%$ based on 1 standard deviation of multiple $\mathrm{Hg}$ vapor injections. Precision is also indicated by examining variability in daily permeation source calibrations (Figure 3). Accuracy was estimated (there are no NIST-traceable $\mathrm{Hg}$ vapor standards) to be $<3 \%$ using $\mathrm{Hg}$ vapor injections.

4. The mass (sample air) flow controller on the 2537A is calibrated at 6-month intervals using a Gillibrator ${ }^{\circledR}$ bubble flow meter. The last calibration prior to this deployment was completed on June 28,2005 and was found to be $2 \%$ greater than actual flow.

5. Three zero-checks were performed on the entire sampling system (inlet lines, filters, and 2537A) during the 2-week sampling period--at initial startup (7/22), 7-day denuder change (7/29), and last day of sampling (8/5). All checks produced 0 output on the 2537A (both counts and $\mathrm{ng} / \mathrm{m}^{3}$ ), which indicates there was no internal mercury contamination in the system. The Tekran output for these results are contained in Appendix A.

6. Three standard addition transport tests were performed on the entire sampling system immediately following the zero checks. Percent recoveries ranged from $95-110 \%$, which indicates the measurements were within $10 \%$ of actual concentrations. The Tekran output for these results are contained in Appendix A.

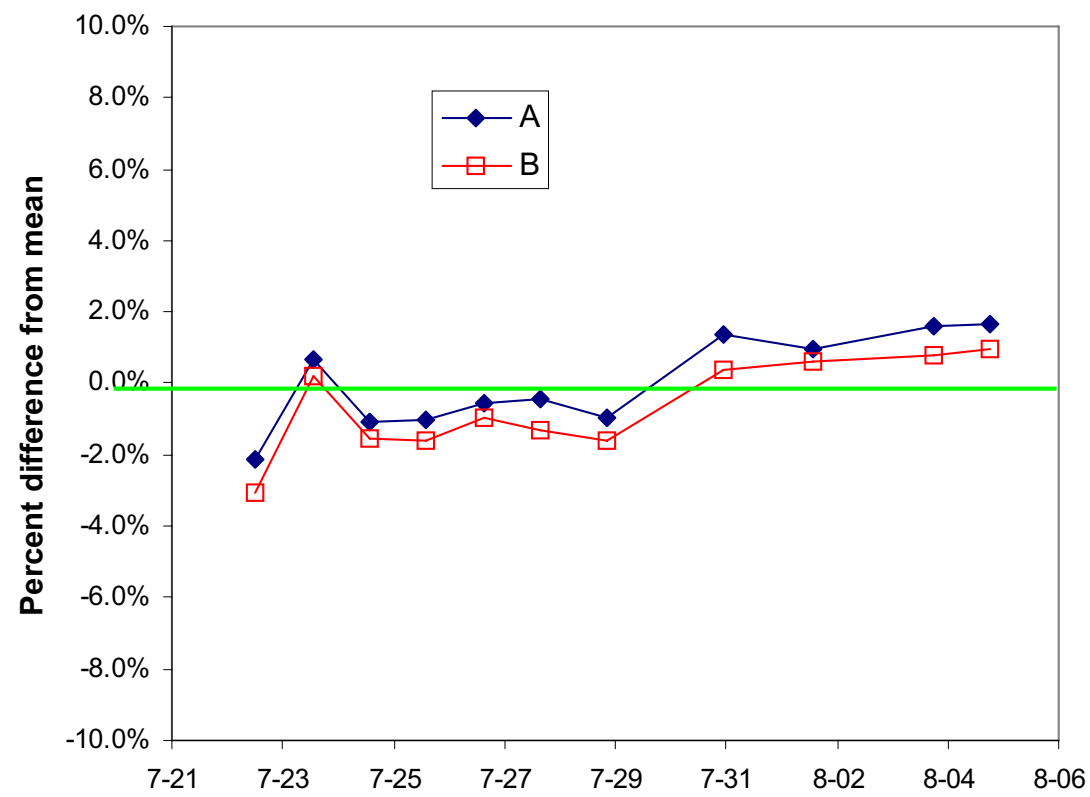

Figure 3. Variability in daily permeation source calibrations was $\pm 1.3 \%$ for both A and B cartridges.

Further QA was performed on the logged data output files generated by the Tekran 2537A. Detector voltage variability (standard deviation) was examined for stability. This procedure resulted in 
replacement of the 2537A UV lamp at the start of the sampling period. Also, the first two 5-min concentrations at the start of the 80-min sampling cycle (sixteen 5-min samples) were examined to determine if they were low due to possible gold cartridge passivation (a problem that sometimes occurs with 1130 denuder operations). These concentrations were deleted (eliminated from the 80-min averaging) if either were less than $80 \%$ of the third 5-min concentration in the cycle (Appendix B).

\section{Results}

The average 80-min EGM air concentration over the 2-week sampling period was $1.9 \pm 0.9 \mathrm{ng} / \mathrm{m}^{3}$ with a range from 1.1 to $8.2 \mathrm{ng} / \mathrm{m}^{3}$ (Figure 4). Global background EGM for the western U.S. is 1.4 to 1.5 $\mathrm{ng} / \mathrm{m}^{3}$ based on long-term measurements made at the INL (Abbott, 2004), $230 \mathrm{~km}$ to the northeast, and measurements currently being made at Mount Bachelor in central Oregon (MBO) (http://research.uwb.edu/jaffegroup) (Figure 5). Overall, the Swan data show at least seven short-term EGM peaks significantly above background $(7 / 22,7 / 24,7 / 28,7 / 29,7 / 30,8 / 1,8 / 2)$, a 3-4-day period where concentrations continuously exceeded background $(7 / 29-8 / 2)$, and two 2-3 day periods with stable background concentrations $(7 / 25-7 / 28$ and $8 / 3-8 / 5)$. The average 2-week EGM concentration at Swan Ranch was determined to be significantly greater $(\mathrm{p}<0.05)$ than the average 2 -week EGM concentration measured on the Snake River Plain (SRP) in southeastern Idaho during the same 2-week period (July 22 - August 5) in 2004 (Figure 6). The diel cycling of EGM concentrations in the INL data (Figure 6) is likely due to surface emissions of EGM during the day caused by photo-reduction of background $\mathrm{Hg}^{+2}$ in the soil (Abbott, 2003).

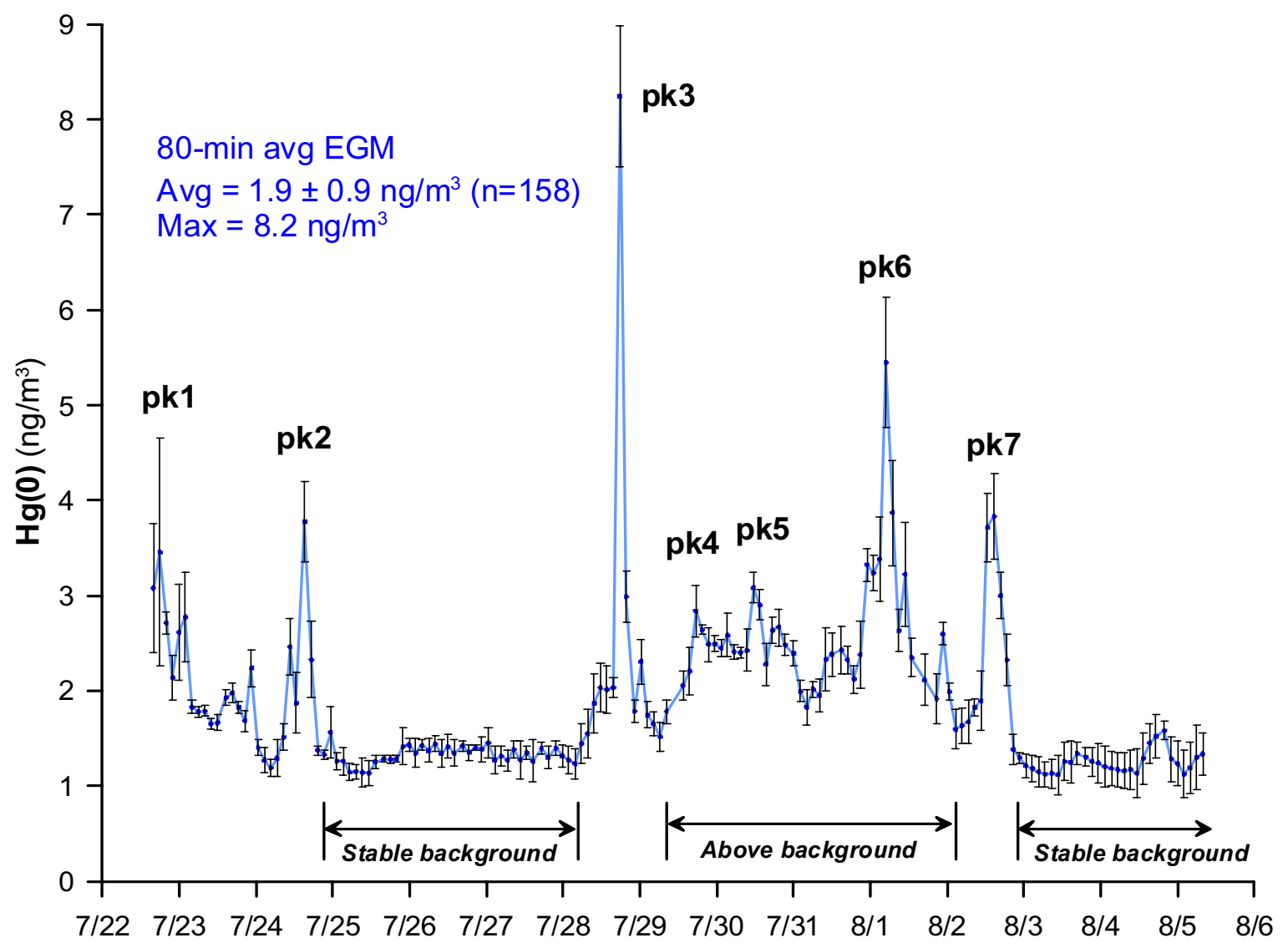

Figure 4. 80-min EGM concentrations measured over the 2-week sampling period at Swan Ranch. 


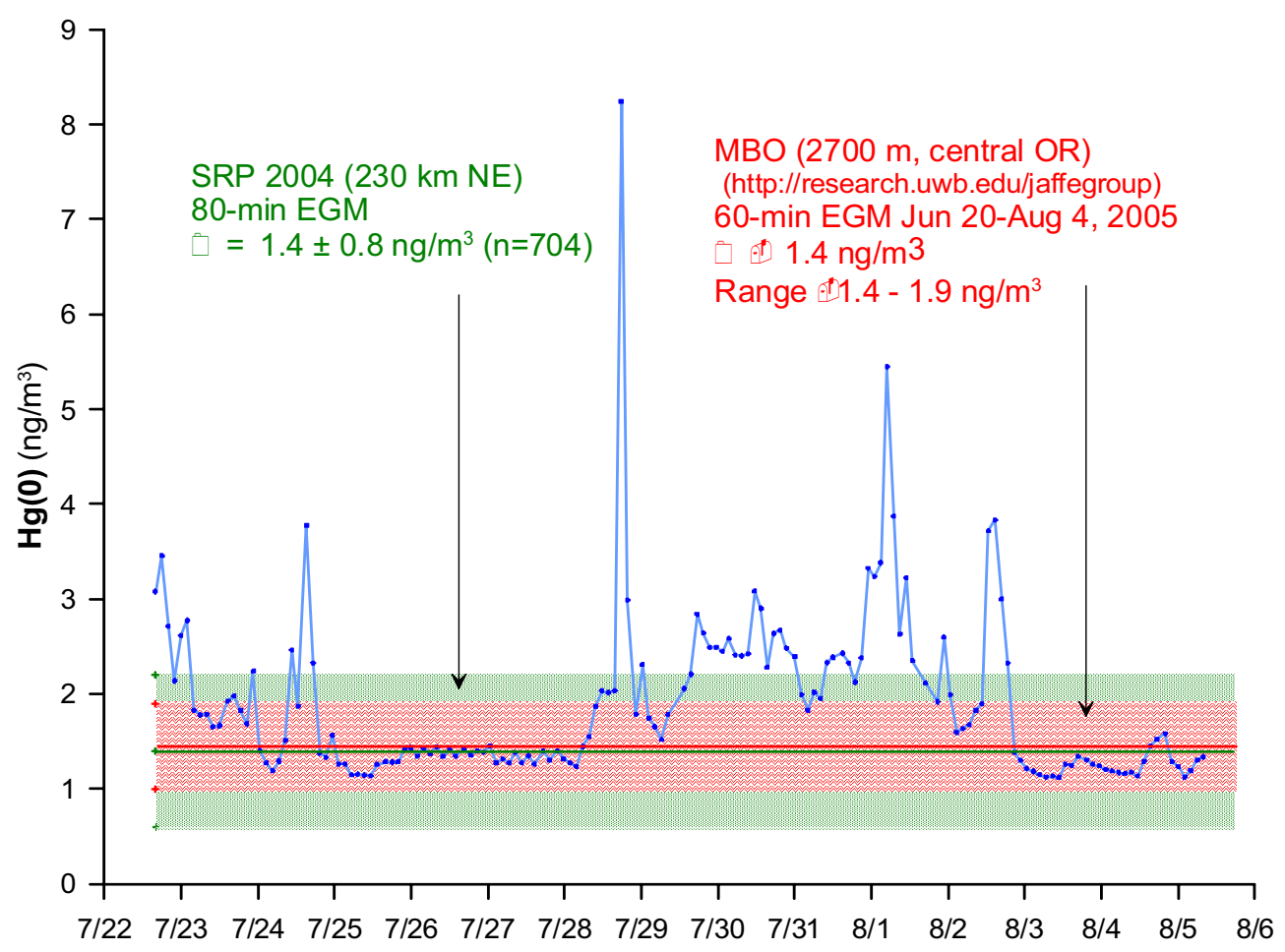

Figure 5. Comparison of measured EGM concentrations with regional background measured on the Snake River Plain (SRP) in southeastern Idaho and at Mt. Bachelor (MBO) in central Oregon (error bars are \pm 1 standard deviation).

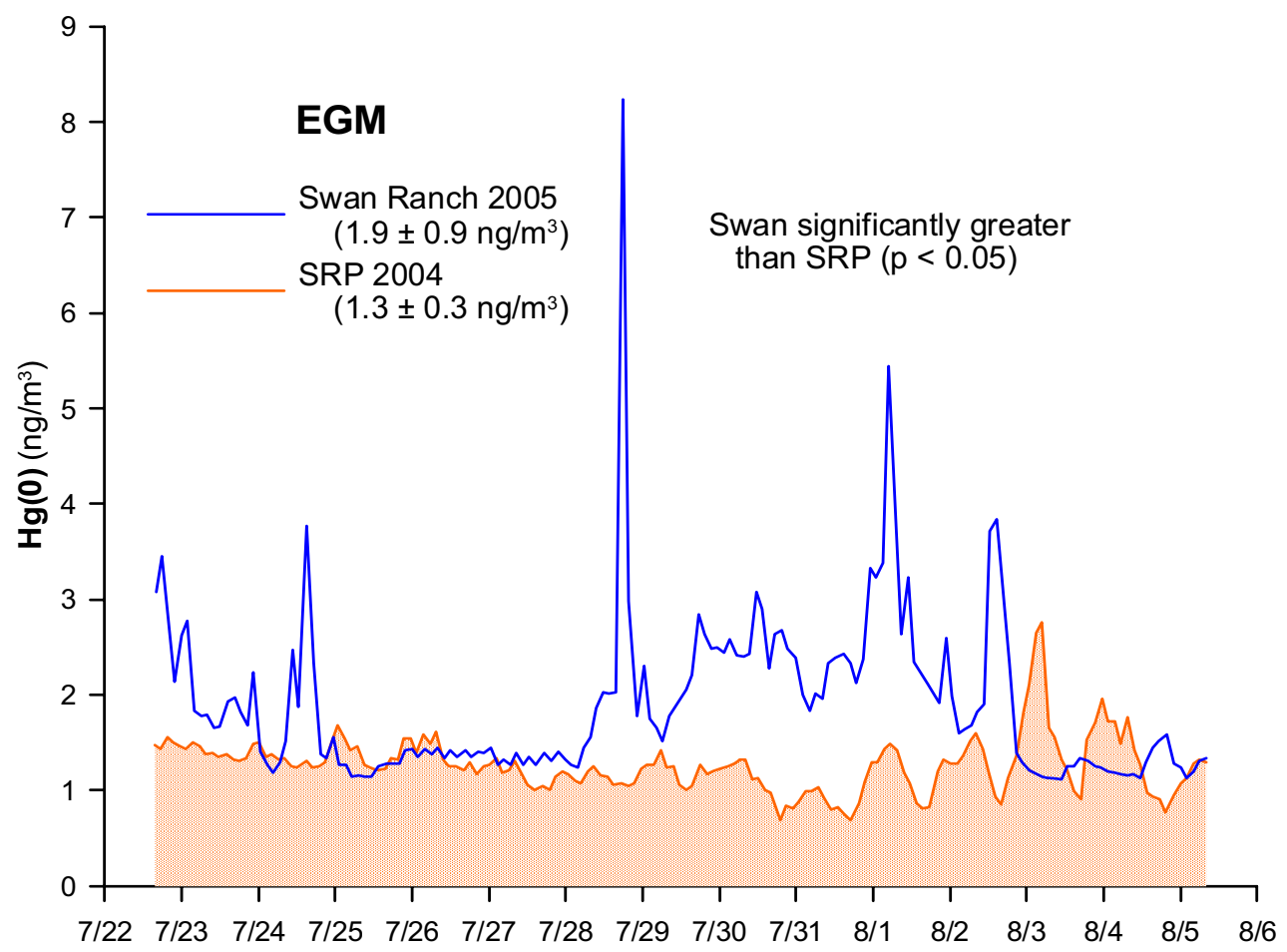

Figure 6. Comparison of EGM at Swan Ranch with EGM measured at SRP over the same 2-week period in 2004. The Swan average was significantly greater than the SRP average $(p<0.05)$. 
The 80-min RGM concentrations measured at Swan Ranch ranged from $1-43 \mathrm{pg} / \mathrm{m}^{3}$ and averaged $8.1 \mathrm{pg} / \mathrm{m}^{3}$ (Figure 7). The diel cycling of RGM, with daytime highs and nighttime lows, suggests production from atmospheric oxidation of EGM during transport. Also of note, is the high RGM peak (on $7 / 28$ ) overlap with the high EGM peak. As with the EGM, the Swan RGM concentrations were significantly greater $(\mathrm{p}<0.05)$ than those measured on the SRP over the same 2-week period in 2004 (Abbott, 2004) (Figure 8).

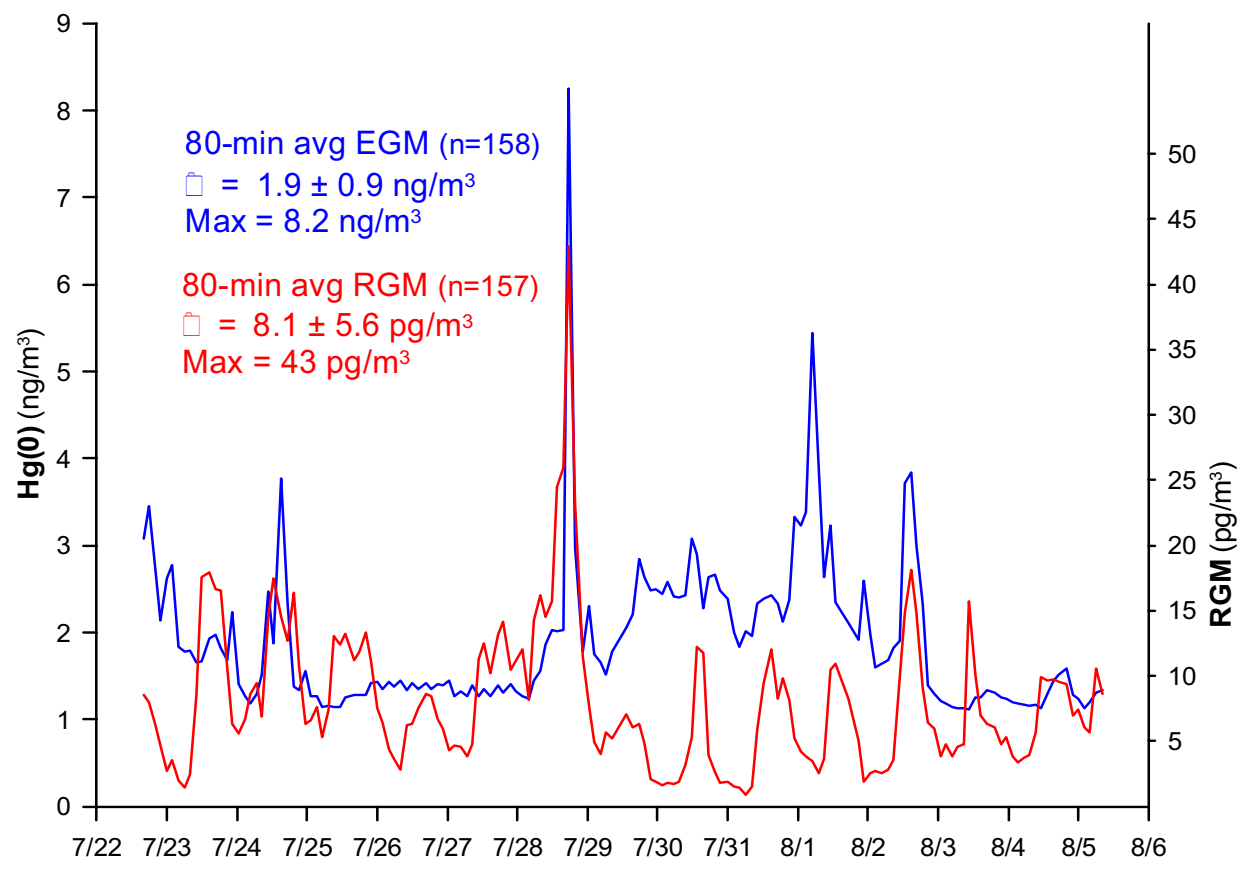

Figure 7. EGM and RGM concentrations measured at Swan Ranch.

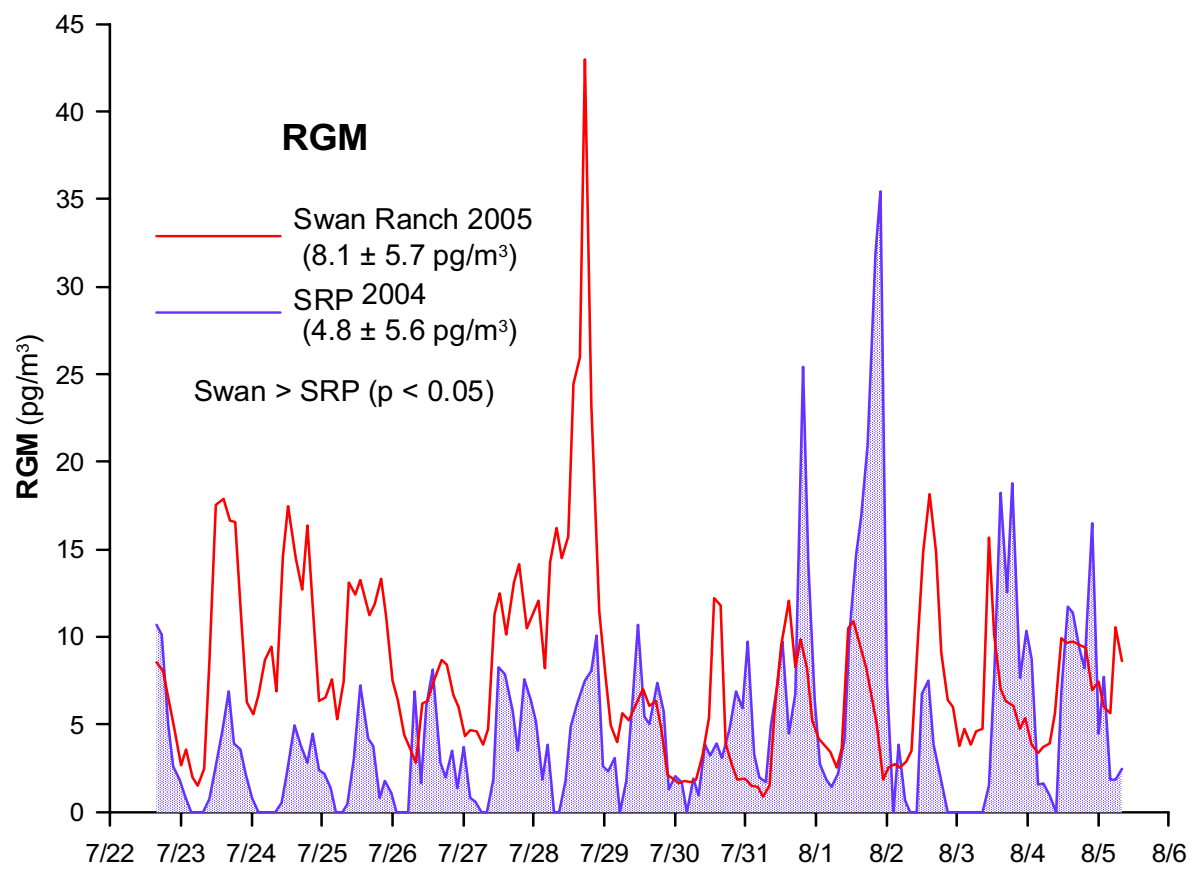

Figure 8. RGM concentrations measured at Swan Ranch compared to RGM on the SRP in 2004. 
The RGM-to-EGM ratio ranged from $0.04 \%$ to $1.4 \%$ and averaged $0.5 \%$ over the two week sampling period. This is a relatively low ratio that probably reflects the amount of in-situ atmospheric oxidation of EGM rather than transport from an RGM-emitting source--the ratio will normally exceed 5\% when sampling in the vicinity of RGM-emitting sources (Sheu and Mason 2001). The $0.5 \%$ ratio during the large EGM peak on 7/28 indicates that the resulting high RGM peak was probably produced by atmospheric oxidation of EGM. This suggests that high regional EGM concentrations may indirectly result in higher total mercury deposition and that regional sources emitting only $\mathrm{Hg}^{0}$ may increase watershed depositional loads.

A back-trajectory is a modeled estimate of where air parcels traveled prior to reaching the sampling site. Back-trajectories were modeled for the seven observed EGM peaks and two EGM background periods (Figure 4) in an effort to identify the general regions where contributing mercury emission sources might be (Figure 9). The NOAA HYSPLIT model with $40 \mathrm{~km}$ ETA data assimilation system (EDAS) grid meteorology was used (http://www.arl.noaa.gov/ready/). The 40-km grid is relatively coarse and does not account for the effects of topography (i.e., mountains) that may influence local flows, although the general flow directions (e.g., northeast Nevada vs. western Idaho) should be fairly accurate. Three 1-hour back-trajectories were run to bracket the peak or background periods observed in the sampling, and each back-trajectory was run with a 24-hr duration. Each trajectory line therefore represents the previous 24-hr path of air parcels that were observed at the sampling location during the 3hours surrounding an event. 

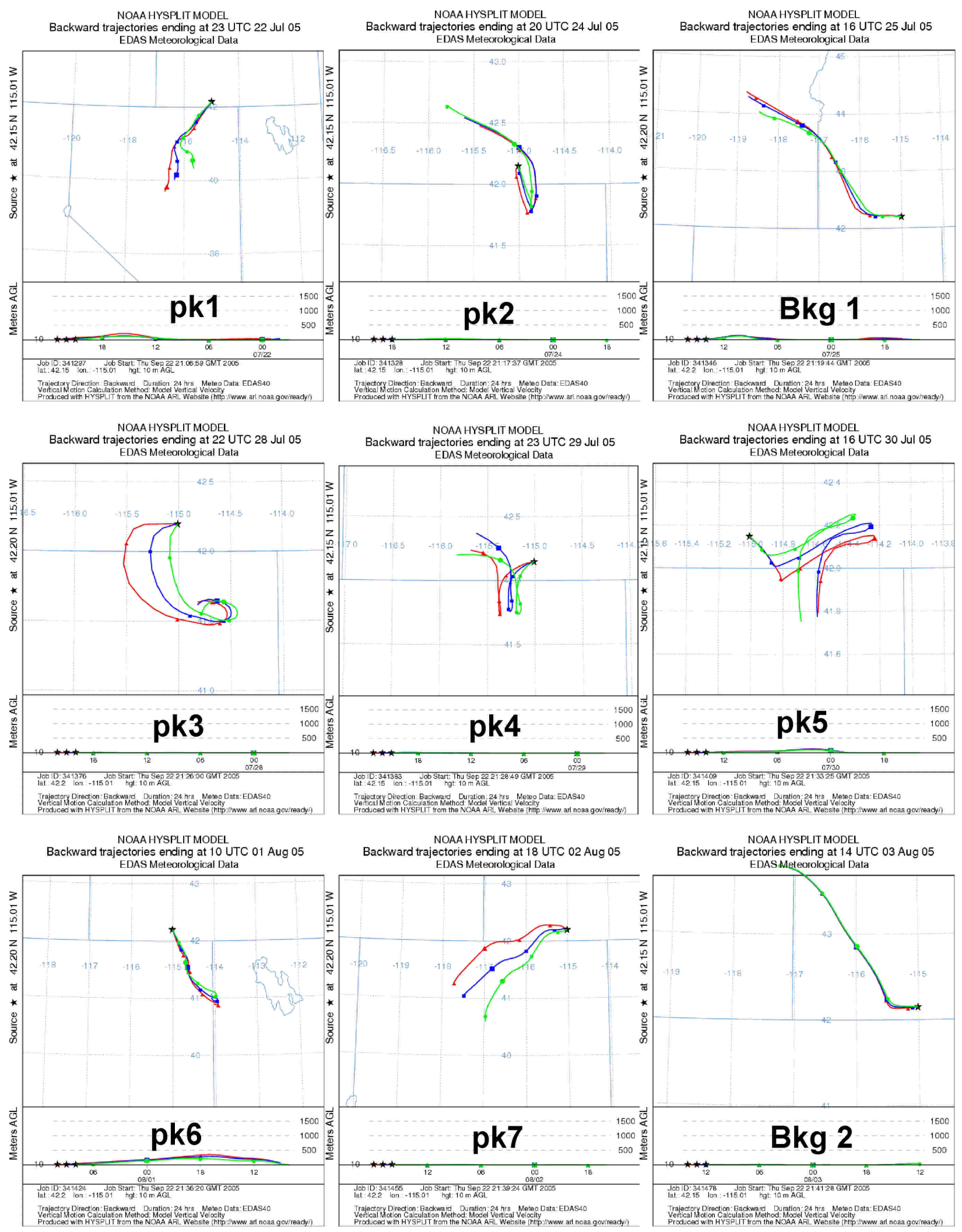

Figure 9. Back-trajectory plots of sampling events shown in Figure 4 (3 trajectories-red, blue, greenshown for 24-hour flow paths ending 1 hour prior to, during, and 1 hour after the event). 
The back-trajectories in Figure 9 show that most of the observed peak concentrations occurred when air masses came out of north-central or northeastern Nevada and that both background periods occurred with clear northwesterly (Idaho) flows. The back-trajectories for peaks 1, 3, and 7 have clear paths through north-central Nevada. Peak 6 seemed to originate in northwestern Utah, flowing through extreme northeastern Nevada to the sampling site. The back-trajectories for peaks 2, 4, and 5 are more complicated-2 and 4 began in Idaho, flowed into northern Nevada, and then recirculated back to the sampling site. Peak 5 started in Nevada, flowed into Idaho well east of the sampling site, then recirculated back to the sampling site. These results suggest three source regions that are contributing to EGM loading in the SFCR watershed: (1) north-central Nevada, (2) northeastern Nevada, and (3) northwestern Utah.

Back-trajectories were also run for each hour of the two-week sampling period (total of 322 backtrajectories) and then assigned to one of four quadrants (northwest, northeast, southeast, southwest, originating at the sampling location) based on where they spent the majority of time in the previous 24 hours (Figure 1). The average EGM concentration was then calculated for each quadrant and the results were statistically compared to one another to determine if one quadrant had higher concentrations. Three statistical tests were used: (1) Wilcoxin rank sum (non-parametric), (2) ANOVA with Duncan's multiple range test, and (3) t-test. The results were the same for all tests: southwest (northeastern Nevada) and southeast (northeastern Nevada and northwestern Utah) quadrants trajectories had statistically higher $(\mathrm{p}<0.05)$ mean/median EGM concentrations than both the northwest and northeast (Idaho) quadrant trajectories. There was no difference in the mean/median concentrations between southwest and southeast quadrants.

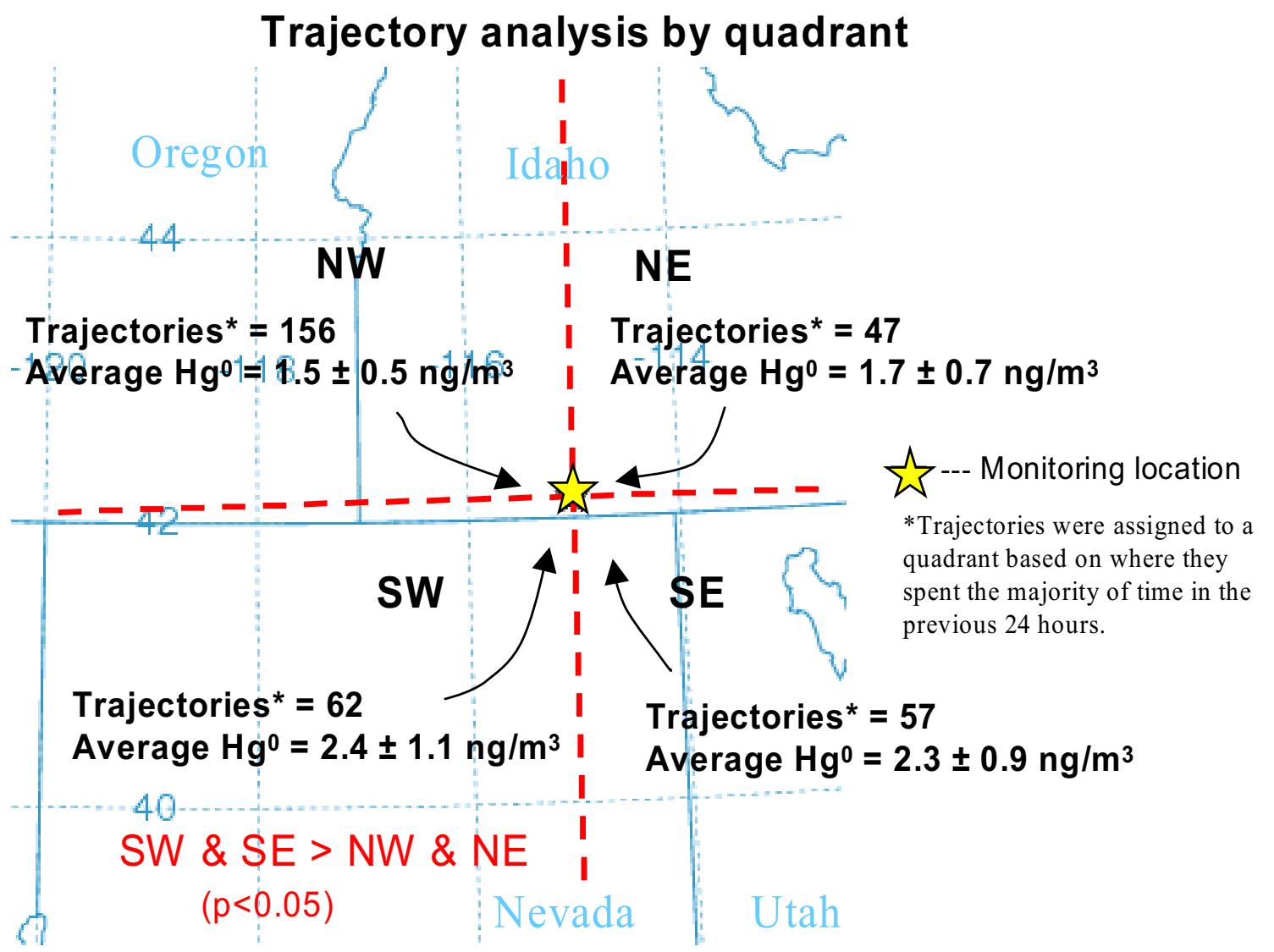

Figure 10. Concentrations from southwest and southeast wind trajectories were significantly greater than concentrations from the northwest and northeast. 
It is known that areas of hydrothermal activity and mercury-enriched substrate across Nevada produce relatively high natural emissions of mercury (mostly elemental) and that their total annual emissions across the State may equal or exceed those from anthropogenic sources (Zenner and Gustin, 2002). Could these natural emissions be the source of the EGM peaks that we observed during our sampling? The largest of these in the back-trajectory regions of interest is the Ivanhoe Mining District approximately $50 \mathrm{~km}$ southwest of Jerritt Canyon Mine and $170 \mathrm{~km}$ southwest of our sampling location. Engle et al. (2001) estimated total emissions of $78 \mathrm{~kg} / \mathrm{y}$ over the $582 \mathrm{~km}^{2}$ of undisturbed naturally enriched substrate in the area. A simple box model (Hanna et al., 1982) can be used to gauge the relative concentration impacts from a source of this magnitude:

$$
C=\frac{\Delta x Q_{A}}{Z_{i} u}
$$

Where

$\Delta \mathrm{x}=$ area source width $(\sim 23,000 \mathrm{~m})$

$\mathrm{Q}_{\mathrm{A}}=$ area-averaged emission rate $\left(78 \mathrm{~kg} / \mathrm{y} / 582 \mathrm{~km}^{2}=4.3 \mathrm{E}-03 \mathrm{ng} / \mathrm{m}^{2} / \mathrm{s}\right)$

$\mathrm{Z}_{\mathrm{i}}=\quad$ mixing depth (assume $100 \mathrm{~m}$ )

$\mathrm{u}=\quad$ annual average wind speed (assume $3 \mathrm{~m} / \mathrm{s}$ )

Using the above values, the estimated fully-mixed concentration over the source area is $0.3 \mathrm{ng} / \mathrm{m}^{3}$. This is an area-averaged concentration, and, although point concentrations over the source would be higher or lower than this, it is a reasonable estimate for judging the relative impacts from this source at our sampling site. Dispersion to the sampling site (over $170 \mathrm{~km}$ ) would enhance mixing and provide dilution of at least 2 orders of magnitude, based on previously-modeled concentration isopleths over this distance. This would give a rough concentration estimate of $3 \mathrm{pg} / \mathrm{m}^{3}\left(0.003 \mathrm{ng} / \mathrm{m}^{3}\right)$ which is below the detection limit of the Tekran and far less than the observed peak concentrations $\left(3-8 \mathrm{ng} / \mathrm{m}^{3}\right)$. 


\section{Conclusions}

The following conclusions are made based on the sampling results and analyses presented above:

1. Two-week average EGM and RGM concentrations are significantly elevated in the SFCR area compared to background. On average, EGM and RGM are $30-70 \%$ higher respectively than background concentrations further north on the Eastern Snake River Plain.

2. Elevated RGM peaks sometimes occurred with elevated EGM peaks. These elevated RGM peaks are likely due to normal atmospheric oxidation of EGM to RGM, rather than local source emissions because: (1) low RGM/EGM ratios existed during the peaks and (2) the sampling location is in a remote location and RGM does not travel far before depositing. This is important because it suggest that high emissions of EGM from local/regional sources may indirectly increase RGM depositional loading in the area.

3. Elevated EGM occurred when air parcels came out of north and northeastern Nevada and extreme northwestern Utah. Background concentrations were observed when the air came out of Idaho. The average concentration in Nevada air masses $\left(2.4 \mathrm{ng} / \mathrm{m}^{3}\right)$ was $40-60 \%$ higher than the average concentration in Idaho air masses $\left(1.4-1.7 \mathrm{ng} / \mathrm{m}^{3}\right)$.

4. Back-trajectory results indicate that there may be several sources to the south of the sampling location that are contributing to EGM loading, but that sources in Nevada are the biggest contributors. The most likely of these are the gold mines in north-central Nevada based on their 2003 EPA TRI emissions estimates and the back-trajectories observed for several of the peak events. Emissions from known large natural sources in that area cannot account for the high concentrations we observed due to their diffuse source geometry and the large $(170 \mathrm{~km})$ transport distance involved. Based on the back-trajectory for one peak EGM event (peak 6 on $8 / 1$ ), some EGM contribution may be from sources in Utah. The most likely of these are Kennecott Mine, west of Salt Lake City, and the Intermountain Power Plant, located near Delta (Figure 1).

5. The measurements made in this study reflect regional source emissions and atmospheric transport during a short time window in late July/early August 2005. Additional monitoring is needed to better define the frequency and magnitude of source contributions in the region and to better quantify long-term seasonal inputs.

\section{References}

1. Abbott, M.L., 2004. INTEC Environmental Sampling FY-04 Annual Report. ICP/EXT-0400572, September.

2. Abbott, M.L., 2003. Environmental Sampling FY-03 Annual Report-Understanding the Movement of Mercury at the INEEL. ICP/EXT-03-01250, October.

3. EPA, 2005, http://www.epa.gov/waterscience/criteria/methylmercury/

4. Sheu, G. and Mason, R.P., 2001. An examination of methods for the measurements of reactive gaseous mercury in the atmosphere. Environ. Sci. Technol. 35, 1209-1216. 
5. Zenner, R.E. and Gustin, M.S., 2002. Estimation of mercury vapor flux from natural substrate in Nevada. Environ. Sci. Technol. 36, 4039-4045.

6. Engle, M.A., Gustin, M.S., and Hong, Z., 2001. Quantifying natural source mercury emissions from the Ivanhoe Mining District, north-central Nevada, USA. Atmos. Environ. 35, 3987-3997.

7. Hanna, S.R., Briggs, G.A. and Hosker, R.P. Jr., 1982. Handbook on atmospheric diffusion. DOE/TIC-11223. 
Appendix A

QA/QC Results 
Table A-1. Daily Tekran permeation source output.

\begin{tabular}{|c|c|c|c|c|c|c|c|c|c|c|c|}
\hline Time & Typ & C & Stat & $\mathrm{FA}$ & dTim & Vol & $\mathrm{BI}$ & BIDev & MaxV & Area & $\mathrm{ng} / \mathrm{m} 3$ \\
\hline $2005-07-22$ 11:52 & ZERO & $A$ & NP & 1 & 300 & 4.99 & 0.094 & 0.039 & 0 & 0 & 0 \\
\hline 2005-07-22 11:57 & ZERO & B & NP & 1 & 300 & 4.99 & 0.095 & 0.051 & 0 & 0 & 0 \\
\hline $2005-07-22$ 12:02 & SPAN & A & OK & 1 & 300 & 4.99 & 0.094 & 0.043 & 0.448 & 1088487 & 30.912 \\
\hline 2005-07-22 12:07 & SPAN & B & OK & 1 & 300 & 4.99 & 0.095 & 0.049 & 0.439 & 1078340 & 30.912 \\
\hline $2005-07-23$ 12:47 & ZERO & A & NP & 1 & 300 & 4.99 & 0.093 & 0.04 & 0 & 0 & 0 \\
\hline $2005-07-23$ 12:52 & ZERO & B & NP & 1 & 300 & 4.99 & 0.093 & 0.064 & 0 & 0 & 0 \\
\hline $2005-07-23$ 12:57 & SPAN & A & OK & 1 & 300 & 4.99 & 0.094 & 0.052 & 0.458 & 1119942 & 30.912 \\
\hline $2005-07-23$ 13:02 & SPAN & B & OK & 1 & 300 & 4.99 & 0.093 & 0.092 & 0.444 & 1114955 & 30.912 \\
\hline $2005-07-24$ 13:27 & ZERO & A & NP & 1 & 300 & 4.99 & 0.094 & 0.055 & 0 & 0 & 0 \\
\hline $2005-07-24$ 13:32 & ZERO & B & NP & 1 & 300 & 4.99 & 0.095 & 0.057 & 0 & 0 & 0 \\
\hline $2005-07-24$ 13:37 & SPAN & $A$ & OK & 1 & 300 & 4.99 & 0.095 & 0.059 & 0.443 & 1100325 & 30.912 \\
\hline $2005-07-24$ 13:42 & SPAN & B & OK & 1 & 300 & 4.99 & 0.095 & 0.069 & 0.44 & 1095077 & 30.912 \\
\hline 2005-07-25 14:07 & ZERO & A & NP & 1 & 300 & 4.99 & 0.096 & 0.047 & 0 & 0 & 0 \\
\hline 2005-07-25 14:12 & ZERO & B & NP & 1 & 300 & 4.99 & 0.095 & 0.044 & 0 & 0 & 0 \\
\hline 2005-07-25 14:17 & SPAN & A & OK & 1 & 300 & 4.99 & 0.095 & 0.054 & 0.446 & 1100957 & 30.912 \\
\hline $2005-07-25$ 14:22 & SPAN & B & OK & 1 & 300 & 5 & 0.095 & 0.041 & 0.428 & 1094580 & 30.912 \\
\hline 2005-07-26 14:47 & ZERO & A & NP & 1 & 300 & 4.99 & 0.095 & 0.038 & 0 & 0 & 0 \\
\hline $2005-07-2614: 52$ & ZERO & B & NP & 1 & 300 & 4.99 & 0.094 & 0.037 & 0 & 0 & 0 \\
\hline 2005-07-26 14:57 & SPAN & A & OK & 1 & 300 & 4.99 & 0.095 & 0.059 & 0.442 & 6127 & 30.912 \\
\hline 2005-07-26 15:02 & SPAN & B & OK & 1 & 300 & 4.99 & 0.095 & 0.049 & 0.435 & 1101809 & 30.912 \\
\hline $2005-07-27$ 15:27 & ZERO & A & NP & 1 & 300 & 4.99 & 0.096 & 0.051 & 0 & 0 & 0 \\
\hline $2005-07-27$ 15:32 & ZERO & B & NP & 1 & 300 & 4.99 & 0.096 & 0.055 & 0 & 0 & 0 \\
\hline $2005-07-27$ 15:37 & SPAN & A & OK & 1 & 300 & 4.99 & 0.096 & 0.048 & 0.441 & 1107340 & 30.912 \\
\hline $2005-07-27$ 15:42 & SPAN & B & $\mathrm{OK}$ & 1 & 300 & 4.99 & 0.096 & 0.046 & 0.433 & 1097567 & 30.912 \\
\hline $2005-07-28$ 20:32 & ZERO & $A$ & NP & 1 & 300 & 4.99 & 0.096 & 0.045 & 0 & 0 & 0 \\
\hline $2005-07-28$ 20:37 & ZERO & B & NP & 1 & 300 & 5 & 0.096 & 0.042 & 0 & 0 & 0 \\
\hline $2005-07-28$ 20:42 & SPAN & A & OK & 1 & 300 & 4.99 & 0.096 & 0.054 & 0.446 & 1101880 & 30.912 \\
\hline $2005-07-28$ 20:47 & SPAN & B & OK & 1 & 300 & 4.99 & 0.096 & 0.049 & 0.439 & 1094518 & 30.912 \\
\hline $2005-07-3022: 17$ & ZERO & A & NP & 1 & 300 & 4.99 & 0.097 & 0.057 & 0 & 0 & 0 \\
\hline $2005-07-30$ 22:22 & ZERO & B & NP & 1 & 300 & 4.99 & 0.097 & 0.055 & 0 & 0 & 0 \\
\hline $2005-07-30$ 22:27 & SPAN & A & OK & 1 & 300 & 4.99 & 0.097 & 0.044 & 0.46 & 1127799 & 30.912 \\
\hline $2005-07-30$ 22:32 & SPAN & B & OK & 1 & 300 & 4.99 & 0.097 & 0.043 & 0.446 & 1116839 & 30.912 \\
\hline 2005-08-01 13:47 & ZERO & A & NP & 1 & 300 & 4.99 & 0.097 & 0.043 & 0 & 0 & 0 \\
\hline 2005-08-01 13:52 & ZERO & B & NP & 1 & 300 & 5 & 0.097 & 0.053 & 0 & 0 & 0 \\
\hline 2005-08-01 13:57 & SPAN & A & OK & 1 & 300 & 4.99 & 0.097 & 0.062 & 0.461 & 1123468 & 30.912 \\
\hline 2005-08-01 14:02 & SPAN & B & OK & 1 & 300 & 4.99 & 0.097 & 0.054 & 0.439 & 1119468 & 30.912 \\
\hline $2005-08-03$ 17:32 & ZERO & $A$ & NP & 1 & 300 & 4.99 & 0.098 & 0.05 & 0 & 0 & 0 \\
\hline 2005-08-03 17:37 & ZERO & B & NP & 1 & 300 & 4.99 & 0.098 & 0.049 & 0 & 0 & 0 \\
\hline 2005-08-03 17:42 & SPAN & A & OK & 1 & 300 & 4.99 & 0.099 & 0.059 & 0.451 & 1129990 & 30.912 \\
\hline 2005-08-03 17:47 & SPAN & B & OK & 1 & 300 & 4.99 & 0.098 & 0.035 & 0.451 & 1121472 & 30.912 \\
\hline 2005-08-04 18:12 & ZERO & A & NP & 1 & 300 & 4.98 & 0.098 & 0.054 & 0 & 0 & 0 \\
\hline $2005-08-04$ 18:17 & ZERO & B & NP & 1 & 300 & 4.99 & 0.098 & 0.057 & 0 & 0 & 0 \\
\hline 2005-08-04 18:22 & SPAN & A & $\mathrm{OK}$ & 1 & 300 & 4.99 & 0.098 & 0.043 & 0.452 & 1130716 & 30.912 \\
\hline 2005-08-04 18:27 & SPAN & B & OK & 1 & 300 & 4.99 & 0.098 & 0.038 & 0.442 & 1122840 & 30.912 \\
\hline
\end{tabular}


Table A-2. Tekran sample system zero air and standard addition checks on 7/22, 7/29, and 8/5/05.

\begin{tabular}{|c|c|c|c|c|c|c|c|c|c|c|c|}
\hline Time & Typ & C & Stat & $\mathrm{F}$ & AdTim & Vol & $\mathrm{BI}$ & BIDev & MaxV & Area & $\mathrm{ng} / \mathrm{m} 3$ \\
\hline $2005-07-22$ 12:13 & CLN & $A$ & NP & 0 & 0 & 0 & 0.094 & 0.05 & 0 & 0 & 0 \\
\hline 2005-07-22 12:17 & CLN & $\mathrm{B}$ & NP & 1 & 216 & 3.66 & 0.095 & 0.043 & 0 & 0 & 0 \\
\hline 2005-07-22 12:20 & CONT & $A$ & NPF & 1 & 300 & 5 & 0.094 & 0.073 & 0 & 0 & 0 \\
\hline $2005-07-22$ 12:25 & CONT & B & NP & 0 & 300 & 4.99 & 0.095 & 0.052 & 0 & 0 & 0 \\
\hline $2005-07-22$ 12:30 & CONT & A & NP & 0 & 300 & 4.99 & 0.095 & 0.073 & 0 & 0 & 0 \\
\hline $2005-07-22$ 12:35 & CONT & B & NP & 0 & 300 & 4.99 & 0.095 & 0.048 & 0 & 0 & 0 \\
\hline $2005-07-22$ 12:40 & CONT & A & NP & 0 & 300 & 4.99 & 0.095 & 0.048 & 0 & 0 & 0 \\
\hline $2005-07-22$ 12:45 & CONT & B & OK & 0 & 300 & 4.99 & 0.094 & 0.052 & 0.257 & 514157 & 14.754 \\
\hline $2005-07-22$ 12:50 & CONT & A & OK & 0 & 300 & 4.99 & 0.094 & 0.049 & 0.271 & 537740 & 15.287 \\
\hline $2005-07-22$ 12:55 & CONT & B & NP & 0 & 300 & 5 & 0.094 & 0.044 & 0 & 0 & 0 \\
\hline 2005-07-22 13:00 & CONT & A & NP & 0 & 300 & 4.99 & 0.094 & 0.044 & 0 & 0 & 0 \\
\hline 2005-07-29 9:23 & CLN & $A$ & OK & 0 & 0 & 0 & 0.098 & 0.045 & 0.1 & 4098 & 0 \\
\hline 2005-07-29 9:27 & CLN & B & OK & 1 & 216 & 3.66 & 0.098 & 0.068 & 0.116 & 60430 & 0 \\
\hline 2005-07-29 9:30 & CONT & $A$ & NPF & 1 & 300 & 4.99 & 0.097 & 0.039 & 0 & 0 & 0 \\
\hline 2005-07-29 9:35 & CONT & B & NP & 0 & 300 & 4.99 & 0.098 & 0.035 & 0 & 0 & 0 \\
\hline 2005-07-29 9:40 & CONT & A & NP & 0 & 300 & 4.99 & 0.097 & 0.045 & 0 & 0 & 0 \\
\hline 2005-07-29 9:45 & CONT & B & NP & 0 & 300 & 4.99 & 0.097 & 0.038 & 0 & 0 & 0 \\
\hline 2005-07-29 9:50 & CONT & A & NP & 0 & 300 & 4.99 & 0.098 & 0.045 & 0 & 0 & 0 \\
\hline 2005-07-29 9:55 & CONT & B & OK & 0 & 300 & 5 & 0.098 & 0.052 & 0.265 & 539123 & 15.24 \\
\hline $2005-07-29$ 10:00 & CONT & A & OK & 0 & 300 & 4.99 & 0.097 & 0.082 & 0.272 & 561116 & 15.763 \\
\hline 2005-07-29 10:05 & CONT & B & NP & 0 & 300 & 4.99 & 0.097 & 0.041 & 0 & 0 & 0 \\
\hline $2005-07-29$ 10:10 & CONT & A & NP & 0 & 300 & 4.99 & 0.097 & 0.046 & 0 & 0 & 0 \\
\hline 2005-08-05 9:03 & CLN & $A$ & OK & 0 & 0 & 0 & 0.1 & 0.047 & 0.102 & 4059 & 0 \\
\hline 2005-08-05 9:07 & CLN & $\mathrm{B}$ & OK & 1 & 216 & 3.66 & 0.1 & 0.038 & 0.102 & 5505 & 0 \\
\hline $2005-08-05$ 9:10 & CONT & $A$ & NPF & 1 & 300 & 4.99 & 0.1 & 0.05 & 0 & 0 & 0 \\
\hline 2005-08-05 9:15 & CONT & B & NP & 0 & 300 & 4.99 & 0.1 & 0.057 & 0 & 0 & 0 \\
\hline 2005-08-05 9:20 & CONT & $A$ & NP & 0 & 300 & 4.99 & 0.1 & 0.042 & 0 & 0 & 0 \\
\hline 2005-08-05 9:25 & CONT & B & NP & 0 & 300 & 4.99 & 0.1 & 0.083 & 0 & 0 & 0 \\
\hline 2005-08-05 9:30 & CONT & A & NP & 0 & 300 & 4.99 & 0.099 & 0.045 & 0 & 0 & 0 \\
\hline 2005-08-05 9:35 & CONT & B & OK & 0 & 300 & 4.99 & 0.1 & 0.049 & 0.257 & 523480 & 14.433 \\
\hline 2005-08-05 9:40 & CONT & A & OK & 0 & 300 & 4.99 & 0.099 & 0.064 & 0.272 & 554689 & 15.186 \\
\hline 2005-08-05 9:45 & CONT & B & NP & 0 & 300 & 4.99 & 0.1 & 0.06 & 0 & 0 & 0 \\
\hline 2005-08-05 9:50 & CONT & $A$ & NP & 0 & 300 & 4.99 & 0.1 & 0.04 & 0 & 0 & 0 \\
\hline
\end{tabular}




\section{Appendix B}

\section{Processed Tekran Data}

(separate file: Table B Tkout) 


\section{Appendix C}

INL Tekran® Mercury Measurement System QA/QC Protocol August 18, 2005

(Separate file: App C - INL Tekran QC 8-18-05) 